\title{
Distribution of the antlion Dendroleon pantherinus (Neuroptera: Myrmeleontidae) in the Czech Republic
}

\begin{abstract}
Distribution of the antlion Dendroleon pantherinus (Neuroptera: Myrmeleontidae) in the Czech Republic. - Acta Mus. Siles. Sci. Natur., 67: 1-6, 2018.

Abstract: This paper summarizes the records of Dendroleon pantherinus (Fabricius, 1787), a European species of antlion belonging to rare and threatened taxa, in the Czech Republic. The species is associated with an ancient xerothermic broadleave forest habitat. So far, D. pantherinus was recorded only a few times in the Czech Republic - always in the southernmost part of Moravia. Several new records of the species from Moravia and Silesia are given. These are Nivnice, Mohelno, Mašovice (in southeast Moravia) and Bukovec (near the Czech-Polish border, in Silesia), where several specimens were sampled, mostly in the dwellings. Therefore, we presume at least partially synanthropic life history of the species.
\end{abstract}

Key words: Dendroleon, faunistics, Moravia, Silesia, Czech Republic

\section{Introduction}

Dendroleon pantherinus (Fabricius, 1787) represents a termophilous Eurosibirian faunal element distributed from the southwestern Europe, through the Balkan Peninsula as far as to the Caucasus Mts. (Colombo et al. 2013). Unlike the majority of its relatives, the predatory larvae of $D$. pantherinus do not dig the typical conical pits in sandy soils to trap passing ants or other prey. Instead, they develop in shady sheltered places, e.g. in hollows of old deciduous trees filled with dry detritus (Roubal 1936). According to various authors, D. pantherinus is a typical species associated with mature oak forests of lowlands (Aspöck et al. 1980, Gepp \& Hölzel 1989), which apparently avoids too arid habitats (Acevedo et al. 2014, Badano \& Pantaleoni 2014).

The first record of the species in the Czech Republic dates to the second half of the seventies (Zelený 1977). Since then, only a few localized records of the antlion have been added, all of them came from southern Moravia. Zelený (2005) pointed out the threat of the species related to the felling and removing of the old hollow oaks and chestnuts and classified the antlion as the critically endangered (CR) species in the Red List of endangered invertebrates of the Czech Republic.

The aim of presented paper is to summarize notes of Dendroleon pantherinus occurrence in the Czech Republic, including new records.

\section{Methods}

We list all existing records of $D$. pantherinus from Moravia and Silesia below. New records are presented with the following information: locality (defined by geographic coordinates, the number of faunistic code of the Central European mapping grid system and altitude), date of collection or observation, number of specimens, collector (leg.), author of identification (det.), deposition of the specimens (coll.), if known, and references in case the data has been published. Concurrently, we add any potentially important information about the locality, if available. In case of formerly published records, we present the localization (using the name, cadastral area and number of faunistic code) and refer to the information source first reporting species in the particular locality. Localities are arranged in ascending order according to the number of faunistic code of the Central European mapping grid system KFME (sensu Pruner \& Míka 1996). 


\section{Results}

\section{Faunistic survey of Dendroleon pantherinus (Fabricius, 1787) in Moravia and Silesia}

We summarize the records of $D$. pantherinus from Moravia and Silesia. New records, previously published notes as well as non-specified published data on the occurrence are listed, the text is supplemented with the grid faunistic map with all the localities marked (Fig. 1).

\section{New records}

Bukovec, 49³3'6.1"N, 1849'33.2"E (6478b), 450 m a. s. 1., 1. IX. 2017, 1 ex., D. Gomolová leg. (the specimen photodocumented and recorded in NDOP - Nature Conservation Agency CR database of faunistic and floristic records).

Note to the locality: family house with garden, street No. 54, Bukovec. Dead imago was found inside the building on the window ledge. Residential area of the village is surrounded with meadows and pastures.

Mohelno, $49^{\circ} 6^{\prime} 29.6^{\prime \prime} \mathrm{N}, 16^{\circ} 11^{\prime} 13.0^{\prime \prime E}$, (6863c), 350 m a.s.1., 1. VIII. 2016, 1 ex., O. Machač observ. (the record is documented by photos of the specimen).

Note to the locality: slopes of the forest-steppe habitat inside the Mohelenska hadcova step Nature Reserve. Observed one flying imago during daytime.

Nivnice, $48^{\circ} 57^{\prime} 11.5^{\prime \prime} \mathrm{N}, 17^{\circ} 38^{\prime} 48.1^{\prime \prime} \mathrm{E}$ (7071b), $310 \mathrm{~m}$ a. s. 1., 4. VII. 2016, 1 o (dead imago inside the building); 27. VIII. 2016, 1 क (imago attracted to the outdoor lighting of the object; Fig. 2); 19. VIII. 2017, 1 ô (dead imago inside the building), all T. Kuras leg., det. et coll.

Note to the locality: old recreational object situated separately, close to the edge of deciduous forest.

Mašovice, 48 $50^{\prime} 51.490^{\prime \prime} \mathrm{N}, 15^{\circ} 59^{\prime} 42.520^{\prime \prime} \mathrm{E},(7161 \mathrm{~d}), 370 \mathrm{~m}$ a.s.1., VI. 2002, 2 ex., P. Janšta observ.

Note to the locality: the two cadavers (imagoes) of the species recorded inside the chata Ještěrka Hut.

\section{Published records}

Vranov nad Dyjí Chateaux (7160b), cadastral area (= c.a.) Vranov nad Dyjí

Ref.: Ševčík (2010)

Note: 1 ex.

Staré vinice (7161d), c.a. Hnanice

Ref.: Šumpich (2015)

Note: 1 ex.

Šobes (7161d), c.a. Podmolí

Ref.: Šumpich (2015)

Note: 1 ex.

Fládnická challet (7161d), c.a. Hnanice

Ref.: Ševčík (2010)

Note: 2 ex.

Kraví hora Mt. near Znojmo (7162c), c.a. Nový Šaldorf-Sedlešovice

Ref.: Kačírek (1995)

Note: 1 ex.

Břeclavská alley (7266d), c.a. Valtice

Ref.: Čížek \& Procházka (2010)

Note: incomplete faunistic record.

Kančí obora near Břeclav (7267a), c.a. Břeclav

Ref.: Holuša (1997)

Note: 1 ex., larva found in a dry detritus of a hollow oak, larva has been subsequently reared to imago. 
Ranšpurk National Nature Reserve (7367b), c.a. Lanžhot

Ref.: Kačírek (1995)

Note: 1 ex.

Pohansko (7267c), c.a. Břeclav

Ref.: Laštůvka et al. (2016)

Note: incomplete faunistic record.

Unspecified records - precise localization is missing

Břeclav env.

Ref.: Zelený (1992)

Lednice env.

Ref.: Zelený (1995)

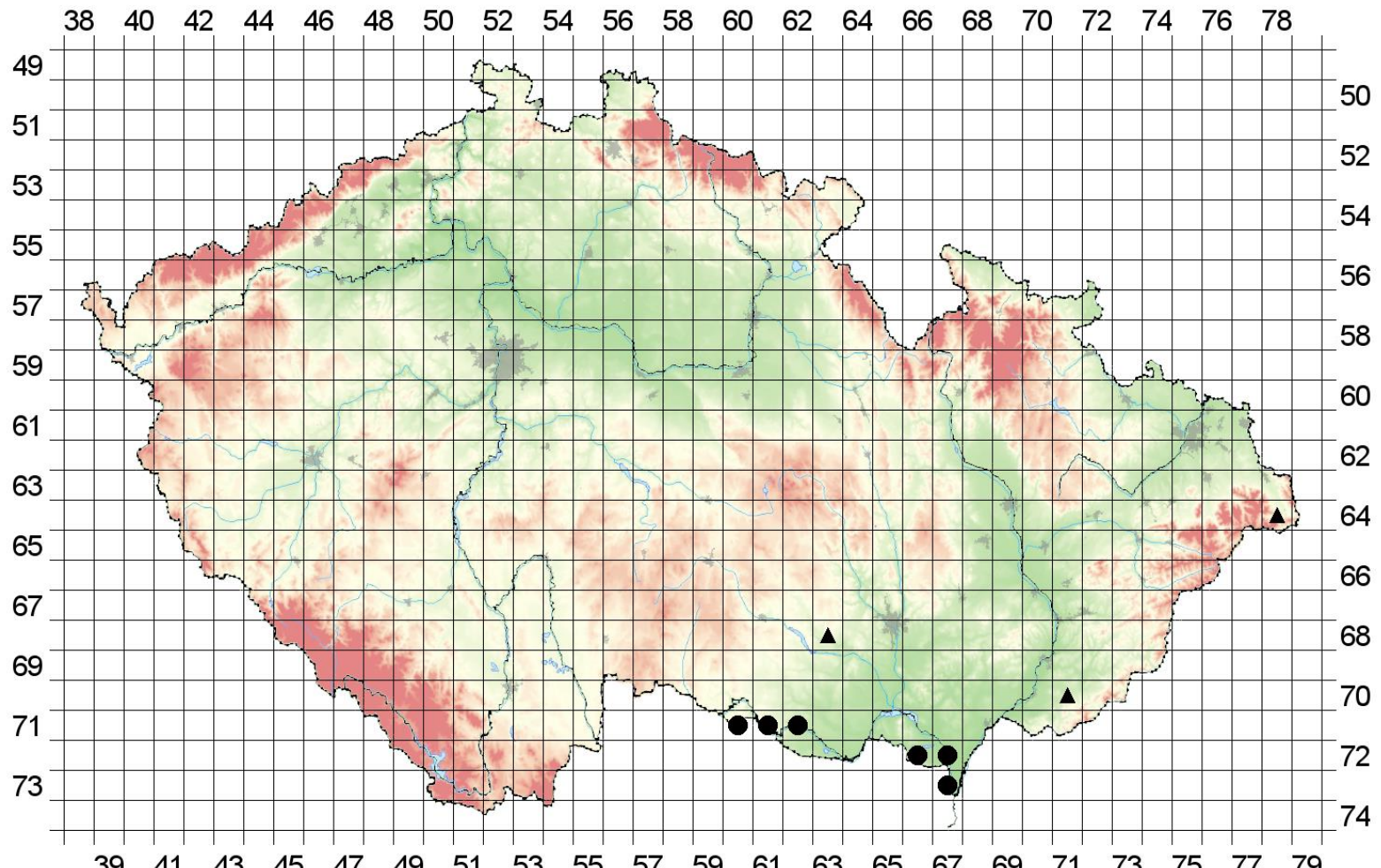

Fig 1: Distribution of Dendroleon pantherinus, an endangered antlion, in the Czech Republic. Previously published records are denoted with $\bullet$; so far unpublished, new records of the species are marked by

\section{Discussion and conclusions}

Considering the existing faunistic notes on distribution of Dendroleon pantherinus, the species apparently belongs to the rarest representatives of Neuroptera in the Czech Republic. Current faunistic records comprise only a few specimens (ca. 10 ex.) occurring strictly in the termophilic oak forests situated in southern Moravia (e.g. Podyjí, Lednice-Valtice region, Soutok). Nevertheless, the species distribution probably extends to other well-preserved oak forest localities in the south Moravia. 
D. pantherinus was newly found in the region of Bílé Karpaty Mts. (Nivnice, 5 ex.), the Českomoravská vrchovina Highlands (Mohelno, 1 ex.), the Podyjí Region (Mašovice, 2 ex.; Podmolí 1 ex.) and in the Silesian Beskydy Mts., nearby the Polish border (Bukovec, 1 ex.). The latter record is surprizing, considering the only known finding of the antlion from Poland comes from the surroundings of Wilczyn village from the first half of $19^{\text {th }}$ century (Rotermund 1837). The species is currently regarded to be extinct in Poland. The record from Nivnice is the first documented occurrence of $D$. pantherinus in the Bíle Karpaty Protected Landscape Area. All of the newly found localities are situated on the northernmost edge of distribution area of the species (Aspöck et al. 1980).

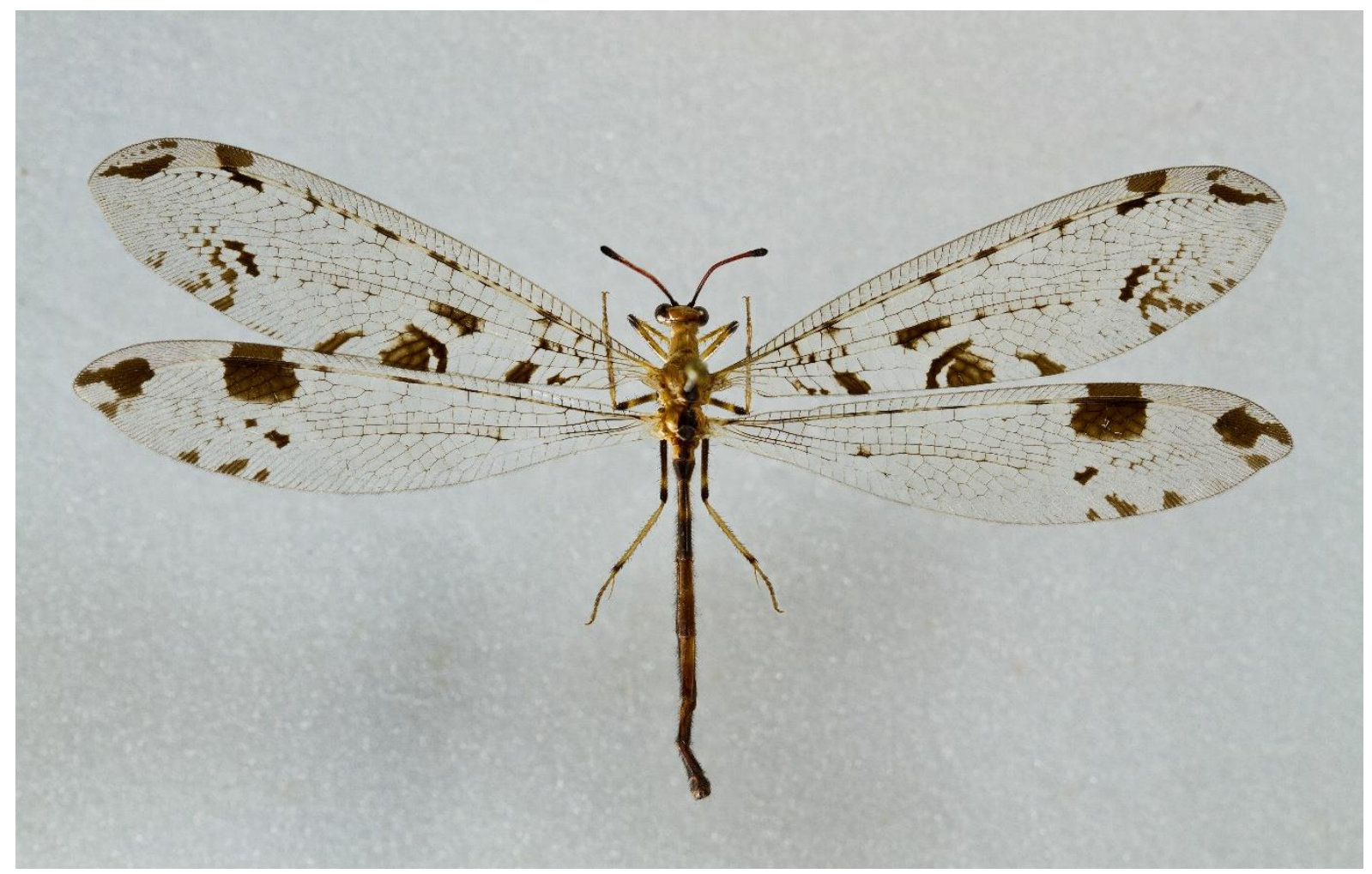

Fig 2: Imago of Dendroleon pantherinus sampled 27. VIII. 2016, at the farm building near Nivnice (foto Ota Blahoušek).

We emphasize also the habitat of the newly recorded specimens. Noteworthy, most of them were observed/found in dwellings. Larvae of this antlion are reported by various authors to develop in hollows with dry detritus and under bark (Roubal 1936, Acevedo et al. 2014). However, Gepp (2010) and Badano \& Pantaleoni (2014) pointed out the partial synanthropy, i.e. the species is able to colonize suitable microhabitats inside the dwellings. The new records (but also some of the former ones) confirm this assumption. The favoured habitat of the antlion (i.e. termophilic oak forests with old hollow trees) lacks in the surroundings of the objects where the species was newly found. Forests are virtually absent nearby Bukovec; though the surroundings of the locality near Nivnice is covered by forest stands (Pannonic oak-hornbeam forest), these do not contain old, hollow trees enabling the larval development. Furthermore, several other speciemens were recorded inside buildings (see Fladnická chalet, chalet Ještěrka etc.). Hence we can conclude the imagoes developed inside the buildings. Alternatively, as "specimens are attracted" by artificial light, they could 
have flown inside from the surroundings, laid there eggs and hence the following generation of the antlion developed there.

D. pantherinus is considered to be the termophilic species bound to old-grown, light forests. However, new records indicate the species might be able to colonize suitable secondary habitats and successfuly develop inside human dwellings. In other words, we consider this antlion to be a partially synanthropic species. Although $D$. pantherinus belongs to relatively large species, it might be overlooked due to the night activity and hidden larval development. Thus, the distribution of this antlion might be probably more extensive than we can conclude on

the basis of existing records.

Acknowledgement: Our particular thanks are given to Dominika Gomolová (Bukovec) and Tomáš Minks (Písek) for specification of the record from Bukovec. Martin Škorpík (Lukov) and Ondřej Machač kindly specified the records from the Podyjí National Park, respectively the Mohelenská step National Reserve. We are also grateful to Dušan Vrchovský (Zlín) and Monika Čadová (Korytná) for an access to the recreational object nearby Nivnice and for stimulating evening discussions beneath the outdoor lighting, leading to the first specimen observation.

\section{References}

Acevedo F., Badano D. \& Monserrat V.J. (2014): The larva of Tricholeon relictus Hölzel \& Monserrat, 2002 a synanthropic antlion (Neuroptera, Myrmeleontidae). - Zootaxa 3835(3): 364-370.

Aspöck H., Aspöck U. \& Hölzel H. (1980): Die Neuropteren Europas. Eine zusammenfassende Darstellung der Systematik, Ökologie und Chorologie der Neuropteroidea (Megaloptera, Raphidioptera, Planipennia) Europas. Goecke and Evers, Krefeld, Germany, $495+355$ pp.

Badano D. \& Pantaleoni R.A. (2014): The larvae of European Myrmeleontidae. - Zootaxa 3762(1): 1-71.

Colombo R., Bruand Y. \& Danflous S. (2013): Contribution à la connaissance de Dendroleon pantherinus (Fabricius 1787) (Neuroptera: Myrmeleontidae). - Revue de 1'Association Roussillonnaise d'Entomologie 22(2): 47-53.

Č́ižek L. \& Procházka J. (2010): Případ Břeclavské aleje aneb jak peníze na ochranu př́rody zaplatily likvidaci ohrožených tvorů. - Živa 58(3): 131-133.

Gepp J. \& Hölzel H. (1989): Ameisenlöwen und Ameisenjungfern. Myrmeleonidae. Die Neue Brehm-Bücherei 589. A. Ziemsen Verlag, Wittenberg Lutherstadt, $108 \mathrm{pp}$.

Gepp J. (2010): Ameisenlöwen und Ameisenjungfern. Myrmeleontidae. Eine weltweite Betrachtung unter besonderer Berücksichtigung Mitteleuropas. 3., neubearbeitete Auflage. Die Neue Brehm-Bücherei 589. Westarp Wissenschaften-Verlagsgesellschaft, Hohenwarsleben, Germany, 168 pp.

Holuša J. (1997): Výskyt mravkolvů Distoleon tetragrammicus (Fabricius, 1798) a Dendroleon pantherinus (Fabricius, 1787) na Moravě (Myrmeleontidae, Neuroptera). - Sborník Př́rodovědného klubu v Uherském Hradišti 2: 109-110.

Kačírek A. (1995): Nové a zajímavé nálezy mravkolvů v České republice (Neuroptera, Myrmeleontidae). - Acta Musei Reginaehradecensis, Ser. A 24: 67-70

Laštůvka Z., Barták M., Bezděk J., Bílý S., Čelechovský A., Dolný A., Hula V., Chládek F., Ježek J., Kment P., Malenovský I., Řezníčková P., Říha M., Skuhravá M., Stejskal R., Šefrová H., Tkoč M., Trnka F. \& Vašátko J. (2016): Červená kniha ohrožených druhů bezobratlých lužních lesů Biosférické rezervace Dolní Morava. Lesnická práce, Kostelec nad Černými lesy, 260 pp.

Pruner L. \& Míka P. (1996): Seznam obcí a jejich částí v České republice s čísly mapových polí pro sítové mapování fauny. - Klapalekiana 32(Suppl.): 1-175.

Rotermund W. (1837): Myrmeleon formicarius und Myrmeleon pantherinus in Heidewilxen, Kr. Trebnitz, Übers. - Arbeiten Schlesischen Gesellschaft für vaterländische Cultur (1836): 86.

Roubal J. (1936): Dendroleon pantherinus F. - Časopis České Společnosti Entomologické 33: 172-173

Ševčík J. (2010): Neuroptera, Raphidioptera and Mecoptera of the Podyjí National Park (Czech Republic). Čas. Slez. Muz. Opava (A) 59: 103-112

Šumpich J. (2015): Records of three rare ant-lion (Neuroptera: Myrmeleontidae) species from the Czech Republic. - Acta Musei Moraviae, Scientiae biologicae (Brno) 100(1): 17-22.

Zelený J. (1977): Planipennia (Neuroptera). Pp. 129-131. In: Dlabola J. (ed.): Enumeratio Insectorum Bohemoslovakiae. - Acta Faunistica Entomologica Musei Nationalis Pragae Suppl. 4: 1-158. 
- (1992): Mravkolev okatý Dendroleon pantherinus (Fabricius, 1787) a mravkolev Myrmeleon bore (Tjeder, 1941). Pp. 81-82. In: Š kapec L. (ed.): Červená kniha ohrožených a vzácných druhů rostlin a živočichů ČSFR. Díl 3, Bezobratlí. Príroda, Bratislava, 157 pp.

- (1995): Planipennia. Pp. 221-226. In: Rozkošný R. \& Vaňhara J.: Terrestrial Invertebrates of the Pálava Biosphere Reserve of UNESCO II. - Folia Facultatis scientiarum naturalium Universitatis Masarykianae Brunensis. Biologia 93: 1-406.

- (2005): Neuroptera (sítokř́ílí). Pp. 163-165. In: Farkač J., Král D. \& Škorpík M. (eds): Červený seznam ohrožených druhů České republiky. Bezobratlí. Red list of threatened species in the Czech Republic. Invertebrates. Agentura ochrany prírody a krajiny ČR, Praha, 760 pp.

Authors' addresses: Tomáš Kuras \& Monika Mazalová, Department of Ecology and Environmental Sciences, Faculty of Science, Palacký University Olomouc, Šlechtitelů 241/27, 78371 Olomouc - Holice, Czech Republic.

E-mail: tomas.kuras@upol.cz,monika.mazalova@upol.cz 